rectum, running along the upper surface of the bowel. The boy was then put under the influence of chloroform, to allow of a more thorough exanination being made. With one hand placed over the pubes, whilst the leg was rotated, a distinct crepitus was detected. Auother attempt was made to pass the catheter; and, after some difficulty, IIr. Lawson succeeded in putting a silver one into the bladder, which ho fastened in by tapes.

July :(j. He was doing well. A gum-clastic catheter was passed to-day, as the lad had drawn the silver one out in the night. The bladder was quite paralysed, and the uriue would only flow through the catheter, when pressure with the hancl was applied above the pubes. On this account, a long India-rubler tube was connected with the end of the catheter, and caricd over the side of tbo bed into a chamber-pot, so as to form a siphon and thus keep the bladder empty.

From this time, the boy progressed uninterruptedly towarils recovery, and was discharged from the bospital on August 20th to attend as an out-patient. He was able to walk about, and had complete command over his bladder.

\section{Ooriginal Communiations.}

\section{TREATMENT OF ABSCESS IN TIIE HAND.}

By W. F. Morgan, Esq., Consulting.Surgeon to the Bristol Loyal Infirmary.

Soxe weelis ago a gentleman applied to me with an abscess in the palm of his hand, deeply seated amongst the tendons. 'The matter was evacuated by incision; and he was directed to bathe the hand in warm water three or four times daily, freely moving the fingers each time; and in the intervals to keep it extencied on a splint. By steadily pursuing this mode of treatment he speedily recovered, and snon regained the perfect use of his hand. The local applications were a poultice at first, and water-dressing subsequently.

I am induced to publish this my usual plan of managing such cases, from an impression that the principle it involves, namely, the early movement of the fingers as a preventive of adhesions and contractions, is not sufficiently recognised. These abscesses are not uncommon amongst the labouring classes; and it is of the first consequence to their welfure to give the patient again an available hand as soon as possible. If the hand be kept day after day on a pillow or splint, and moved only en massc, the suro result will be a long confinement, and probably more or less permanent impairment of its functions.

\section{SCABIES SUCCESSFULLY TREATED WITH COAL-TAR NAPHTHA.}

By Sayruel Spratry, Esy., late Senior Resident Surgeon to tho Birmingham General Dispeusary, and Surgeon to the Albar Reformatory Frigate.

In the number of the Brtrish Miedrcal Journal for September $28 \mathrm{th}$, there appeared a letter from Mr. Godfrey of Malvern, strongly recommending the application of benzine to the surface of the body in the case of itch. We have had several intractable cases which have slowly yielded to the inunction of sulphur ointment. The frequent occurrence of fresh cases in those boys just discharged from the gaols to the Akbar to undergo their period of committal, together with difficulties of keeping the infected boys from the rest, and the length of time required in the treatment by sulphur before the cure can be pronounced complete, determined me on the first opportunity to make a trial of the remedy above named.
On Monday, September 30th, a very bad case was discovered in a boy, aged 15. I sent for some benzine, but, unable to procure it, made use of a much cheaper remedy, viz., coal-tar naphtha, which is, like benzine, a curbide of hydrogen, and nearly identical in obomical cowposition. The patient was made to sponge himealf thoroughly with it, and was kept apart from the rest of the bojs. The next morning the itching had entirely ceased, and the eruption appeared dying away; his clothes were well boiled, and at the end of three days he was allowed to return to his duty in the ship, and from that time to the present there has not been the slighteet symptom of return.

It is hardly fair to judge from the success of one case, but I trust that the naphtha will have a fair trial: and should it prove a speedy and effectual cure for this $\vec{A}$ disease, it will prove a great boon to the profession $w$ at large.

Rock lierry, Oct. 23ru, 1861.

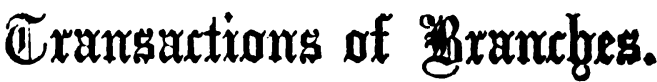

\section{READING BRANCH.}

RETROBPECTIVE ADDRESS OF THE READTHO PATHOLOGICAL BOCIETY.

By O. C. Maurice, Esq., House-Surgeon to the Royal Berkshire Hospital.

[Read July 2.1th.]

Mr. Presinfent and Gentlemen,-Being the juniono nember of this Society, I feel that $I$ should be wantip. in respect to myself, as well as to you, were I not to mat 300 some apology for addressing you this evening; buts having been assured that those who are far better alge huve declined, I have consented to do my best.

My duty appears to resolve itself into giving ahartô resumé of those subjects brought under our notice during the past year, together with such fow remarks as my vary limited experience will ailow; and I trust that, althougho my address will be found very far from faultless, your indulgence will be extended to one who from his com-? parative inexperience cannot but enter upon it with foel-o. ings of the greatest diftidence.

Before proceeding to the more immediate subjeot in hand I must crave your attention for a few moments.

This is the twentieth anniversary of our Societs io $^{\circ}$ and as in each succeeding month we look forward with pleasure to our meetings, with how much greaters? satisfaction must we hail this our anniversary, wheno we meet together to review the deeds of the pest year, and endeavour to arrive at the conclusion that it havo not been wasted or frittered away, but that we have one and all made some contribution, small thongh itcr may have been, for the advancement of soienes and $D$ the raising of our profession.

Societies like the present have been reoognised bJ and received the sanction of the highest and most dis $N$ tinguished members of our profession, as not only useful in themselves, but also as being the means of uniting in bonds of friendship the difierent members of it.

And let us remember that there is no more noble pros fession than ours, which has for its objeot not only the? prolongation of life and the alleviation of sutiering and sickness; great as these may be, it belongs also to us teo fathom the depths of nature, and to endesvour, as far cD possible, to unravel the all-wise ways of Providencof through which we live and move and have our being.

And although upon these researches many or all of the collateral sciences are frequently brought to bears and although our metropolitan societies have facilities 